\title{
The Blue Water Footprint of Block-printed Batik Coloured by Natural Dye of Myrobalan (Terminalia bellirica Roxb.) Mordanted by Alum and Copperas
}

\author{
Widhi Handayani ${ }^{1}$, Alberta Rika Pratiwi ${ }^{2}$, Budi Widianarko ${ }^{2}$ \\ \{widhyandayani@gmail.com ${ }^{1}$, pratiwi@unika.ac.id², widianarko@unika.ac.id²
}

Satya Wacana Christian University, J1. Diponegoro 52-60 Salatiga, Central Java, Indonesia ${ }^{1}$, Soegijapranata Catholic University, Jl. Pawiyatan Luhur IV/1 Semarang, Central Java, Indonesia ${ }^{2}$

\begin{abstract}
The batik production by home industries in Central Java, Indonesia, has been creating surface water pollution because of synthetic dyes, and triggers to its replacement by natural dyes. However, the use of natural dye could consumes more water, as the fabric should be immersed into the extract repetitively, which make up to the high of Blue Water Footprint. This study aims to examine the Blue Water Footprint (BWF) of batik production coloured by Myrobalan (Terminalia bellirica Roxb.) extract. An experiment was conducted in a large-scaled batik home industry in Jarum village, Klaten. White block-printed cotton fabrics, Myrobalan extract, and alum and copperas were used for the experiment, while water usage were calculated. The BWF of block-printed batik of both treatments were $156.48-158.70 \mathrm{~L} / \mathrm{pc}$ or $68.52 \mathrm{~L} / \mathrm{m}^{2}$ of fabric, on average, which is mainly contributed by the dewaxing process. Implementing cleaner production, hence, is central to increase water use efficiency.
\end{abstract}

Keywords: Home industry; Block-printed batik; Blue water footprint; Mordant; Terminalia bellirica Roxb.

\section{Introduction}

Batik is commonly understood as textile product which is produced by traditional handcraft. In fact, it is a process of drawing where a resist dye technique is involved by applying the wax on the cloth to prevent certain parts of the cloth from being coloured, in order to create patterns [1]. Indonesian batik is a product which is usually produced by home industries. The batik production often releases wastewater without proper treatment [2]. As a consequence, the discharge of the wastewater pose negative impact to aquatic environment [3]. This negative impact is often correlated to the use of synthetic dyes which are reported to contain carcinogenic compounds and difficult to decompose and this has been promoting the revival of natural dyes for global textile colouration, as the latter is considered to be ecofriendly [4]. Unfortunately, our previous study showed that applying natural dyes for batik production does not necessarily changes the production to be more eco-friendly [5].

In natural dyeing, a white cotton cloth should be soaked into natural dyes extracts in turns with drying, and those steps are done repeatedly until an expected colour is formed [6]. Repeated cloth-soaking means absorbing the liquid extract of dyes, and because the water will be evaporated during the drying process, this pattern corresponds to the consumptive water use which is a component of Blue Water Footprint [7]. The consumptive water use probably works for Myrobalan (Terminalia bellirica Roxb.) because in order to form an expected 
colour from it, the cloth should be soaked into its extract for many times. The more frequent the cloth is dipped into the extract, the more water that will be absorbed. On the final step of dyeing, the batik artisans are usually adding mordants such as alum and copperas, because the mordants play a significant role in forming the final colour.

Studies on water usage for batik have been reported, mainly in regard to cleaner production [8] and eco-efficiency measurement [9], [10], [11]. Nevertheless, those researches were conducted using Life Cycle Assessment (LCA), Data Envelopment Analysis (DEA), and other approaches which measure the use of resources to produce batik in general, instead of merely water. However, the approach used to measure water usage only based on its direct use to produce batik, which is commonly different from the water footprint approach. The water footprint approach consists of three components of Blue Water Footprint, Green Water Footprint, and Grey Water Footprint [7]. The Blue Water Footprint is an indicator of consumptive water use of blue water or freshwater, which includes (1) evaporated water; (2) water that incorporated in the product; (3) water that does not return to the same catchment area, and (4) water that does not return in the same period after its withdrawal [7]. This is the difference between the mentioned approaches and the water footprint.

Studies on water footprint of batik production have been reported [12], [13]. Unfortunately, these studies were focused on the general production of batik and did not attempt to specifically explain the consumptive water use of batik production by application of a specific dye. Therefore, this study aims to examine the Blue Water Footprint (BWF) of batik production coloured by natural dye extract of Myrobalan (T. bellirica Roxb.) mordanted by alum (aluminium sulphate) and copperas (ferrous sulphate).

\section{Methods}

This research was conducted in a batik home industry which produces block-printed batik by natural dyeing and one of the natural dye used for dyeing is Myrobalan (T. bellirica Roxb.). This research is conducted in Jarum village because some areas of this village sometimes suffer from drought in dry season and batik production during this season could be disturbed due to the drought, in addition to the reason explained by [5]. By this study, we are seeking an opportunity to encourage the batik artisans to improve the water usage management.

As explained in the previous section, the BWF includes (1) evaporated water; (2) water which is incorporated in the product; (3) water which does not return to the same catchment area, and (4) water that does not return in the same period after its withdrawal [7]. However, in this research, we consider the three former water uses, i.e. water which is evaporated and incorporated in the cloth, and the water which is used but is not returned in the same area, particularly not as clean as when it was withdrawn. We do not include the water which is saved by the artisan, because they also use the water for domestic purposes and not merely for batik production.

The experiment on the home industry was conducted by preparing six block-printed white cotton clothes of $2.0 \mathrm{~m}$ x $1.15 \mathrm{~m}$ size for each. The Myrobalan extract was prepared by the batik artisan by their own formulae. The clothes were weighed and treated to pass the whole batik making-process as usually performed by the batik artisan. All processes were observed and consumptive water use regarding to the water absorbed by the cloth during dyeing process were calculated based on Equation 1. 


$$
v=\left(\frac{w_{1}-w_{0}}{\rho}\right) \times f_{s}
$$

The notation $v$ represents the volume of water absorbed $(\mathrm{ml}), w$ represents the weight $(\mathrm{g})$ of the cloth after soaking $\left(w_{1}\right)$ and before soaking $\left(w_{0}\right), \rho$ represents the density of Myrobalan extract $(\mathrm{g} / \mathrm{ml})$, and $f_{s}$ represents total number of soaking the cloth.

The Equation 1, however, is not appropriate to calculate the water evaporates and lost return flow during dewaxing process, therefore the measurement of the water consumed on that process is conducted based on our previous study [5]. The wax, natural dyes, and water attached or absorbed by each clothes were also measured according to our previous research [13]. Colour measurement of the Myrobalan extract and the coloured clothes were conducted using a Minolta CR-200 chromameter resulting the $L^{*}, a^{*}$, and $b^{*}$ parameters which were used to calculate the total colour change $(\Delta E)[14],[15]$.

\section{Results and Discussion}

\subsection{Colours of block-printed batik by the application of different mordants}

Our result showed that the behaviour of this artisan was similar to our previous study which found that it is unusual for batik home industry artisan to measure the use of materials, such as water [13]. In addition, the process of making block-printed batik by natural dyeing was similar to that of hand-drawn batik as explained previously [5], except that drawing on the cloth is replaced by block-printing and degumming. The block-printed clothes were usually degummed by soaking them for 30 minutes in a detergent solution, followed by washing and drying. After all, the clothes are then ready for colouration. The white block-printed cotton clothes were then coloured by Myrobalan extract by dipping the clothes in turn with drying them under the sun. Three of the clothes were dipped for twelve times, while the three others were dipped for seven times. After the process was finished, the twelve times dipped clothes were mordanted by alum, while the seven times clothes were mordanted by copperas and the results are presented in Fig 1.

$\mathbf{a}$

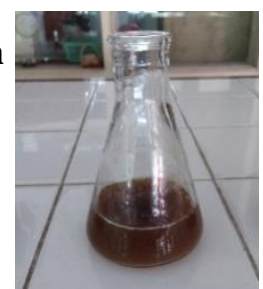

b

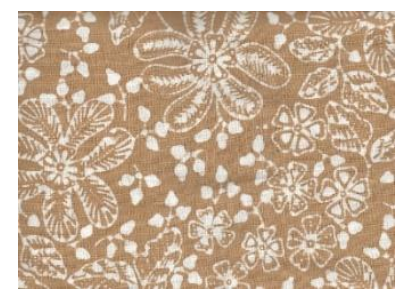

C

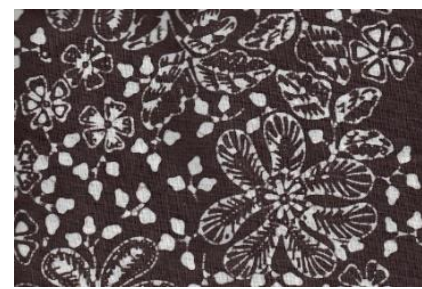

Fig.1. (a) extract of Myrobalan (T. bellirica); (b) block-printed batik cloth after coloured by Myrobalan and mordanted by alum; and (c) block-printed batik cloth after coloured by Myrobalan and mordanted by copperas

This study finds the difference on the colour of block-printed batik clothes after they were mordanted by alum (Fig.1b) and copperas (Fig. 1c). Copperas tends to form a darker colour on the cloth while alum forms a lighter colour. This indicates that frequency of soaking might not strongly influence the final colour, because the colour of Fig. 1b was resulted by repeatedly 
immerse the cloth in Myrobalan extract for twelve times, and only seven times immersion in Myrobalan extract to form the colour of Fig 1c. Other study also reported that the use of aluminium sulphate and ferrous sulphate to mordant fabrics coloured by Acacia nilotica extract forms lighter and darker colours, respectively [16]. Moreover, the reaction between iron ion and tannic acid will results an iron-tannate complex which forms dark shades such as blue-black, green-black, brown, or grey [17]. This correspond to darker colours formed on fabrics coloured by A. nilotica and T. bellirica which were mordanted by copperas, as those plants contain tannin [16], [18].

Table 1. Colour difference of block-printed batik clothes coloured by Myrobalan and fixed by different mordants

\begin{tabular}{ccccc}
\hline Mordants & $\Delta L^{*}$ & $\Delta a^{*}$ & $\Delta b^{*}$ & $\Delta E^{*}$ \\
\hline Alum (Aluminium sulphate) & 25.40 & 2.59 & 19.54 & 32.15 \\
Copperas (Ferrous sulphate) & 15.64 & 1.06 & 2.76 & 15.92 \\
\hline
\end{tabular}

Table 1 shows the colour difference of block-printed batik clothes mordanted by alum and copperas. It is indicated by the $\Delta E$ value that the colour difference is higher on alum than that of copperas, and this is influenced mostly by $\Delta L^{*}$ and $\Delta b^{*}$ values. The $L^{*}$ value refers to lightness of the sample (Magdić et al., 2009). Therefore, higher $L^{*}$ value means higher colour lightness and this is indicated visually as the colour of Myrobalan extract (Fig. 1a) is darker than the clothes mordanted by alum (Fig $1 \mathrm{~b}$ ). The positive $b^{*}$ value indicates tendency to form bright yellowish tone, while the negative refers to blue colour [14], [15]. High value of $\Delta b^{*}$ therefore, indicates a yellow colour, and visually this is in line to the result presented in Fig. $1 \mathrm{~b}$, while lower value of $\Delta b^{*}$ presented by copperas mordanted-cloth (Fig. 1c) tends to indicate a darker yellowish shade. Visually, the colour of Myrobalan extract (Fig.1a) and copperas mordanted-cloth (Fig 1c.) tend to be more similar than that of alum mordanted-cloth.

\subsection{Material usage for block-printed batik production}

Table 2 presents materials usage to produce a block-printed batik of $2.00 \mathrm{~m} \times 1.50 \mathrm{~m}$ size. In general, the water absorbed per $\mathrm{m}^{2}$ and the wax attached onto the cloth mordanted by alum and copperas were similar. It is only the natural dye absorbed by the cloth which indicates the difference between alum and copperas treatment. As indicated in Table 2, the copperas mordanted-cloth absorbed $16.20 \mathrm{~g} / \mathrm{m}^{2}$ Myrobalan dye, and $25.00 \mathrm{~g} / \mathrm{m}^{2}$ of Myrobalan dye was absorbed by the alum mordanted-cloth, and this difference could be related to the frequency of immersion.

Table 2. The materials used to produce a block-printed batik coloured by Myrobalan

\begin{tabular}{cccc}
\hline Mordants & Wax $\left(\mathrm{g} / \mathrm{m}^{2}\right)$ & Myrobalan dye $\left(\mathrm{g} / \mathrm{m}^{2}\right)$ & Water $\left(\mathrm{L} / \mathrm{m}^{2}\right)$ \\
\hline Alum (Aluminium sulphate) & 208.33 & 25.00 & 0.23 \\
Copperas (Ferrous sulphate) & 211.67 & 16.20 & 0.22 \\
\hline
\end{tabular}

In comparison to our previous study, hand-drawn batik which is produced by natural dyeing used $120 \mathrm{~g}$ dye, $430 \mathrm{~g}$ of wax, and absorb $0.29 \mathrm{~L}$ of water per pc of $1.15 \mathrm{~m} \times 2.50 \mathrm{~m}$ fabric [13], which are equal to $41.74 \mathrm{~g} / \mathrm{m}^{2}, 149.56 \mathrm{~g} / \mathrm{m}^{2}$, and $0.10 \mathrm{~L} / \mathrm{m}^{2}$ dye, wax, and water, respectively. This study found that the block-printed batik in this study used less dyes in 
comparison to the hand-drawn batik, and this could be understood because this study only focused on a species of plant for dyeing, while the other batik SME used some species of plants in dyeing. In regard to the use of wax, the difference could be influenced by the motifs, i.e. full batik motifs tend to use more wax than the less ones. Finally, the difference in water absorption by the fabric may be influenced by the kind of the cotton fabric used. It is generally known among batik artisans that there is primissima cotton fabric and prima cotton fabric. The latter is thinner and of lower quality than the primissima. Primissima is usually used to make fine hand-drawn batik, while the block-printed batik is usually made on the prima fabric. The difference in the thickness of the fabric, which is corresponded to the yarn count, could affect the water volume absorbed by the fabric. It is reported that some processes of immersion, capillary sorption, adhesion, and spreading influence the wetting phenomenon of textile structures [19]. However, other study reported that yarn count affected the wetting rate of the fabric. When thin and thick fabrics of the same type of material were compared, the thinner wets faster than the thicker ones when equal amounts of water are applied [20]. This could be the reason that the fabric used for this study absorbed more water than that of the previous study.

\subsection{Blue Water Footprint of block-printed batik coloured by Myrobalan}

Table 3 presents data on the water consumed during the production of block-printed batik. It is indicated by Table 3 that water was consumed in some steps of degumming, dyeing in turns with drying, dewaxing, and final drying. Similar to the previous result, the difference on water usage was found in the dyeing process, in which the water consumed by alum mordanted-cloth was higher than that of copperas mordanted-cloth. Therefore, this might affect the total volume of water consumed during batik production. Nevertheless, it is found that the BWF of block-printed batik of both alum and copperas were mostly similar, i.e. $156.48-158.70 \mathrm{~L} / \mathrm{pc}$ of $2.00 \times 1.15 \mathrm{~m}$ size or equal to $68.52 \mathrm{~L} / \mathrm{m}^{2}$ of batik cloth.

Table 3. The blue water footprint of a block-printed batik coloured by Myrobalan

\begin{tabular}{lccc}
\hline \multicolumn{1}{c}{$\begin{array}{c}\text { Block-printed batik } \\
\text { making-process }\end{array}$} & Unit & $\begin{array}{c}\text { Water usage in a batik making-process } \\
\text { by different mordants }\end{array}$ \\
\cline { 3 - 4 } & & $\begin{array}{c}\text { Alum } \\
\text { Copperas } \\
\text { (Ferrous sulphate) }\end{array}$ \\
\hline Block-printing & --- & 0.00 & 0.00 \\
Degumming & $\mathrm{L} / \mathrm{pc}$ & 0.46 & 0.43 \\
Dyeing & $\mathrm{L} / \mathrm{pc}$ & 4.12 & 1.94 \\
Dewaxing & $\mathrm{L} / \mathrm{pc}$ & 153.89 & 153.89 \\
Final drying & $\mathrm{L} / \mathrm{pc}$ & 0.23 & 0.22 \\
Total Blue Water Footprint & $\mathrm{L} / \mathrm{pc}$ & 158.70 & 156.48 \\
Total Blue Water Footprint & $\mathrm{L} / \mathrm{m}^{2}$ & 69.00 & 68.03 \\
\hline
\end{tabular}

In comparison to other study, this result is higher than the water consumed for blockprinted batik production in Pekalongan which is reported to be $5 \mathrm{~L} / \mathrm{m}$ output $-8 \mathrm{~L} / \mathrm{m}$ output [8]. Another study reported that after introduction of eco-efficiency, the water consumed for block-printed batik production in Pekalongan could reach $1.09 \mathrm{~L} / \mathrm{pc}$ (dyeing), $22.5 \mathrm{~L} / \mathrm{pc}$ (dewaxing), and $37.5 \mathrm{~L} / \mathrm{pc}$ (washing) or $61.09 \mathrm{~L} / \mathrm{pc}$ in total [9]. The result of this study is much 
lower than our results, and this is possible because of the different approach we use for this study. Our result is also much higher than other study which found that in order to produce a block-printed batik of $2.75 \times 1.75 \mathrm{~m}$ in size, $6.41 \mathrm{~L} / \mathrm{pc}$ water is required [12]. In comparison to the benchmark of batik cloth, which is reported as $25-50 \mathrm{~L} / \mathrm{m}$ of cloth [8], this result indicates that the home industry is inefficiently uses water.

This study also found that the highest component in Blue Water Footprint calculation falls to dewaxing process, which includes the water evaporates during boiling and the effluent derived from the dewaxing and washing which were usually discharged without treatment. It should be noted that the artisan was usually used two cubical tanks of (1) $58 \mathrm{~cm}$ in diameter and $30 \mathrm{~cm}$ height and (2) $56 \mathrm{~cm}$ in diameter and $40 \mathrm{~cm}$ height, respectively. The artisan will use these tanks for boiling the clothes whenever he needs to do this task, regardless the number of the clothes. Therefore, in this study, we do not divide the volume of water of the tanks to the number of clothes as doing so will resulting inaccurate calculation. Furthermore, the result of this study is in line to the finding of other study which indicates that $62.85 \%$ of water footprint of textile production in Bangladesh was derived from washing, dyeing, and finishing stage [21]. Nevertheless, it is also reported that Blue Water Footprint makes a $13.85 \%$ up of total Water Footprint in textile production, while the rest is made up by the Grey Water Footprint [21]. Another study in China showed that the GWF of China's textile production could reach $62 \mathrm{Gm}^{3} /$ year, while the highest BWF was only $1.09 \mathrm{Gm}^{3} /$ year [22]. Therefore, in textile production, generally the Blue Water Footprint has a lower portion than the Grey Water Footprint.

Finally, this study indicates that the block-printed batik clothes were unsustainably produced. Efforts to promote awareness of batik artisans in order to increase the efficiency of water usage are central to reduce the water footprint. As systemic environmental problems are related to human behaviour, clean technology is necessary for sustainability while lifestyle changes and human values is the key to protect and preserve the resource [23]. Moreover, treating water effluent and cleaner production are two options which could be implemented in order to reduce the water footprint [24].

\section{Conclusion}

The Blue Water Footprint of block-printed batik coloured by Myrobalan (T. bellirica Roxb.) extract of both treatments were nearly similar, i.e. $156.48-158.70 \mathrm{~L} / \mathrm{pc}$ of $2.00 \mathrm{~m} \mathrm{x}$ $1.15 \mathrm{~m}$, or equal to $68.52 \mathrm{~L} / \mathrm{m}^{2}$, on average. The dewaxing process makes the biggest portion of the Blue Water Footprint. Nevertheless, this study has a limitation as it is not intended for generalization purpose. Future works highlights the need to increase the efficiency of water use by transforming the behaviour of batik artisan, as well as water effluent treatment and implementation of cleaner production.

Acknowledgments. The authors gratefully acknowledge the Directorate of Research and Community Service, Directorate General of Research Enhancement and Development, the Ministry of Research, Technology and Higher Education (KEMENRISTEK DIKTI) of Indonesia who has supported this research in the form of Hibah Pasca Doktor grant under the Contract No. 010/L6/AK/SP2H.1/PENELITIAN/2019. We would also like to acknowledge Felix Sholeh Kuntoro and Stefanus Agung Wicaksono Wibowo who have provided technical assistance to this research. 


\section{References}

[1] UNESCO.: Education and Training in Indonesian Batik Intangible Cultural Heritage in Pekalongan, Indonesia. UNESCO Intangible Cultural Heritage Section, Paris (2013)

[2] Birgani, P.M., Ranjbar, N., Abdullah, R.C., Wong, K.T., Lee, G., Ibrahim, S., Park, C., Yoon, Y., Jang, M.: An efficient and economical treatment for batik textile wastewater continuing high levels of silicate and organic pollutants using a sequential process of acidification, magnesium oxide, and palm shell-based activated carbon application. Journal of Environmental Management, vol. 184, pp. 229239 (2016) https://doi.org/10.1016/j.jenvman.2016.09.066

[3] Sutisna, Wibowo, E., Rokhmat, M., Rahman, D. Y., Murniati, R., Khairujjal, \& Abdullah, M: Batik Wastewater Treatment Using $\mathrm{TiO}_{2}$ Nanoparticles Coated on the Surface of Plastic Sheet. Procedia Engineering, vol. 170, pp. 78-83 (2017) https://doi.org/10.1016/j.proeng.2017.03.015

[4] Patil, S. H., Kurlapkar, D. D., \& Gaikwad, D. K.: Dye-yielding plant resources of Maharashtra, India: A checklist. Biodiversitas, vol. 20(1), pp. 250-266 (2019). https://doi.org/10.13057/biodiv/d200129

[5] Handayani, W., Kristijanto, A. I., \& Hunga, A. I. R.: Are natural dyes eco-friendly? A case study on water usage and wastewater characteristics of batik production by natural dyes application. Sustainable Water Resources Management, vol. 4(4), pp. 1011-1021 (2018). https://doi.org/10.1007/s40899-018-0217-9

[6] Handayani, W., Kristijanto, A. I., \& Hunga, A. I. R.: Behind the eco-friendliness of "batik warna alam": Discovering the motives behind the production of batik in Jarum village, Klaten. Wacana, vol. 19(1), pp. 235-256 (2018). https://doi.org/10.17510/wacana.v19i1.673.236

[7] Hoekstra, A. Y., Chapagain, A. K., Aldaya, M. M., \& Mekonnen, M. M.: The Water Footprint Assessment Manual: Setting the global standard (1st ed.). Earthscan, London (2011)

[8] Nurdalia, I.: Kajian dan analisis peluang penerapan produksi bersih pada usaha kecil batik cap (Studi kasus pada tiga usaha industri kecil batik di Pekalongan). [Master Thesis]. Universitas Diponegoro, Indonesia (2006)

[9] Nindita, V., Purwanto, D., Sustrisnanto, D.: Evaluasi implementasi eko-efisiensi di salah satu usaha kecil menengah batik di kabupaten Pekalongan. Jurnal Riset Teknologi Pencegahan Pencemaran Industri, vol 2(2), pp. 82-91 (2012)

[10] Sari, D. P., Hartini, S., Rinawati, D.I.,Wicaksono, T.S.: Pengukuran tingkat eko-efisiensi menggunakan Life Cycle Assessment untuk menciptakan Sustainable Production di Industri Kecil Menengah Batik. Jurnal Teknik Industri vol. 14(2), pp. 137-144 (2012)

[11] Susanty, A., Hartini, S., Puspitasari D., Arsiwi, P.: Measuring efficiency of using resource in the production process of making stamped-batik: A DEA approach. Mediterranean Journal of Social Sciences vol. 6(5), pp. 318-327 (2015)

[12] Nursanti, I., Djunaidi, M., Munawir, H., \& Putri, E. Y.: Water footprint assessment of Indonesian Batik production. AIP Conference Proceedings, vol. 1977(50008), pp. 3-7 (2018). https://doi.org/10.1063/1.5043012

[13] Handayani, W., Kristijanto, A. I., \& Hunga, A. I. R.: A water footprint case study in Jarum village, Klaten, Indonesia: The production of natural-colored batik. Environment, Development and Sustainability, vol. 21(4), pp. 1919-1932 (2019) https://doi.org/10.1007/s10668-018-0111-5

[14] Magdić, D., Lukinac, J., Jokić, S., Čačić-Kenjerić, F., Bilić, M., \& Velić, D.: Impact analysis of different chemical pre-treatments on colour of apple discs during drying process. Croatian Journal of Food Science and Technology, vol. 1(1), pp. 31-35 (2009)

[15] Geelani, S. M., Ara, S., Mir, N. A., Bhat, S. J. A., \& Mishra, P. K.: Dyeing and fastness properties of Quercus robur with natural mordants on natural fibre. Textiles and Clothing Sustainability, vol. 2(8), pp. 1-10 (2016) https://doi.org/10.1186/s40689-016-0019-0

[16] Ali, A., Ali, S., Shaleem, H., \& Hussain, T.: Effect of Tannic Acid and Metallic Mordants on the Dyeing Properties of Natural Dye Extracted from Acacia nilotica Bark Effect of Tannic Acid and Metallic Mordants on the Dyeing. Asian Journal of Chemistry, vol. 22(9), pp. 7065-7069 (2010)

[17] Wilson, H., Carr, C., \& Hacke, M.: Production and validation of model iron-tannate dyed textiles for use as historic textile substitutes in stabilisation treatment studies. Chemistry Central 
Journal,vol. 6(44), pp. 1-14 (2012) https://doi.org/10.1186/1752-153X-6-44

[18] Kumar, N., \& Khurana, S. M. P.: Phytochemistry and medicinal potential of the Terminalia bellirica Roxb . ( Bahera ). Indian Journal of Natural Products and Resources, vol. 9(2), pp. 97-107 (2018)

[19] Cruz, J., Leitão, A., Silveira, D., Pichandi, D., Pinto, B., Fangueiro, R.: Study of moisture absorption characteristics of cotton terry towel fabrics. Procedia Engineering, vol. 200, pp.389-398 (2017)

[20] Özdil, N., Özçelik, G., Süpüren, G., Průchová, J.: A study on the moisture transport properties of the cotton knitted fabrics in single jersey structure. Tekstil ve Konfeksiyon, vol 3, pp. 218-223 (2009)

[21] Hossain, L., \& Khan, M. S.: Blue and Grey Water Footprint Assessment of Textile Industries of Bangladesh. In 5th International Conference on Chemical Engineering ICChE 2017: Energy, Environment, and Sustainability (pp. 437-449). Dhaka, Bangladesh (2017)

[22] Wang, L., Ding X., Wu, X.: Blue and Grey Water Footprint of textile industry in China. Water Science \& Technology vol. 68(11), pp. 2485-2491 (2013)

[23] Gorobets, A.: Eco-centric policy for sustainable development. Journal of Cleaner Production, vol. 64, pp. 654-655 (2014).

[24] Hossain, L., Sarker, S. K., \& Khan, M. S.: Evaluation of present and future wastewater impacts of textile dyeing industries in Bangladesh. Environmental Development, vol. 26, pp. 23-33 (2018) https://doi.org/10.1016/j.envdev.2018.03.005 